\title{
Growth performance of castor bean hybrids under different plant densities ${ }^{1}$
}

\author{
Laerte Gustavo Pivetta ${ }^{*}$, Camila de Aquino Tomaz ${ }^{3}$,Samuel Luiz Fioreze ${ }^{4}$, Ana Carolina da Costa Lara-Fioreze 4 , \\ Laércio Augusto Pivetta ${ }^{5}$, Maurício Dutra Zanotto ${ }^{6}$
}

$10.1590 / 0034-737 X 201764040009$

\begin{abstract}
Castor bean grown at high plant densities can increase yield due to increased light interception and reduction in sink demand. The objective of this study was to evaluate the effect of plant density on growth of castor bean hybrids. The experiment was conducted in Botucatu, SP, Brazil, in a split plot randomized block design, with four replications, in 2011 and 2012. The main plot consisted of the sampling times and the subplots consisted of a $3 \times 3$ factorial, with the 3 genotypes in the first factor and the 3 plant densities in the second factor. The variables analyzed were: dry mass of leaves, stems, racemes, and total dry matter, which were measured at 30, 60, 90, 120 and 150 days after emergence (DAE). Data were examined for significant differences using analysis of variance followed by the $F$ test $(p<0.05)$. When interaction was found between the factors and sampling the means were analyzed by regression analysis $(\mathrm{p}<0.05)$. Growth performance was higher in 2012 because of the greater water availability. In 2011, under lower rainfall, there was less branching resulting in cycle end, with total leaf loss. High plant densities partially suppress the development of higher-order structures, especially when associated with water restriction.
\end{abstract}

Key words: mechanical harvesting; Ricinus communis L.; spatial arrangement.

\section{RESUMO}

\section{Crescimento de híbridos de mamona sob densidades populacionais adensadas}

O cultivo de mamona sob altas densidades populacionais pode aumentar a produtividade devido à maior interceptação de luz e à redução dos drenos vegetativos. O objetivo desta pesquisa foi avaliar o efeito da densidade populacional de híbridos de mamona sobre o crescimento das plantas. O experimento foi conduzido em Botucatu, SP, em 2011 e 2012. O delineamento experimental utilizado foi de blocos ao acaso organizado em parcelas subdivididas com quatro repetições. As parcelas foram constituidas pelas coletas e as subparcelas foram constituídas por um fatorial $3 \times 3$. O primeiro fator foi composto por três genótipos e o segundo fator por três densidades populacionais. As variáveis analisadas foram matéria seca de folhas, caules, racemos e matéria seca total, realizadas ao 30, 60, 90, 120 e 150 dias após a emergência (DAE). Os dados foram submetidos à análise de variância pelo teste $\mathrm{F}(\mathrm{p}<0,05)$. Quando houve interação entre os fatores e coleta as médias foram analisadas por regressão $(\mathrm{p}<0,05)$. O crescimento foi maior no ano de 2012 devido à maior disponibilidade hídrica. Em 2011, sob menor pluviosidade, houve menor ramificação resultando em fechamento do ciclo, com perda total das folhas nos híbridos. Altas densidades populacionais suprimem parcialmente o desenvolvimento de estruturas de ordem superiores, principalmente quando associadas à restrições hídricas.

Palavras-chave: colheita mecânica; Ricinus communis L.; arranjo espacial.

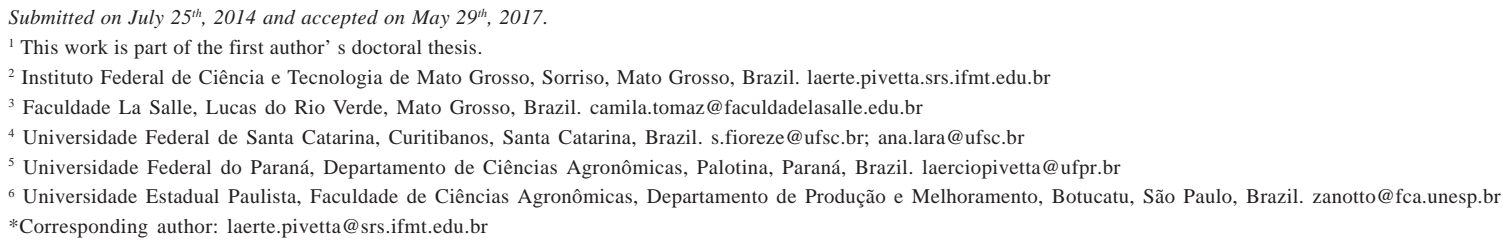




\section{INTRODUCTION}

Castor bean (Ricinus communis L.) belongs to the family Euphorbiaceae and is the sole species of the genus Ricinus. Both Ethiopia and East Africa are mentioned as castor bean's center of origin (Moshkin, 1986). Castor bean was brought to Brazil by the Portuguese and the tropical climate favored its dissemination (Santos et al., 2007). The main product of castor bean is the oil present in its seeds, which has numerous applications including medicinal and cosmetic use, plastic and lubricant manufacturing, fiber optic production, bulletproof glass and bone prostheses (Chierice \& Claro Neto, 2007). Despite its importance, Brazil, once the world's largest producer of castor bean in the 1960-1980 period, was the fourth largest producer accounting only with $1.8 \%$ of world production in 2014, behind China, Mozambique and India, which is world's largest producer with $87 \%$ of world production (FAO, 2014).

To reverse this situation, Brazil needs to invest in new technologies to increase castor bean yield. The development of new genetic materials and crop management improvements are among the technologies. In Brazil, the Mid-West region has great potential for expanding castor bean cultivation. Rangel et al. (2003) analyzed the prospects of castor bean in the state of Mato Grosso and suggest that castor bean can be mechanically cultivated as second crop in the season. The authors argue that to adapt the castor bean crop to the region, with large farms, dwarf sized hybrids should be used to allow mechanical harvesting. Savy Filho (1999) points out that hybrids have specific characteristics of uniformity, early cycle, response to agricultural inputs, size suitable for mechanical harvest, which allow their cultivation by larger and technified producers.

The recommendation for growing castor bean in the Cerrado is to sow the crop approximately between 15 and 20 February. Dallacort et al. (2011) mention that the historical averages (1970 to 2007) of rainfall for the second crop in the Cerrado, Tangará da Serra region, Mato Grosso, are approximately $250 \mathrm{~mm}$ in February, $250 \mathrm{~mm}$ in March, $150 \mathrm{~mm}$ in April, $60 \mathrm{~mm}$ in May, $15 \mathrm{~mm}$ in June, and $20 \mathrm{~mm}$ in July. If we consider half of the February average rainfall, the sum up to July is $620 \mathrm{~mm}$. Weiss (1983) observed that good yields are achieved with rainfall between 375 and 500 $\mathrm{mm}$, evenly distributed in the first 4 months. Under these conditions, it is possible that there is a lower incidence of gray mold due to the reduction in rainfall from May onwards.

Good yields are expected in the Cerrado, but there is a need for alternatives that provide the highest possible yield in these conditions. One strategy that would make the best use of the rains in the first months of cultivation is to adjust plant density. The use of narrow and ultra- narrow spacing altogether with the increase of the number of plants is a common practice in cotton crops and, allows its cultivation as a second crop due to the anticipation of the harvest provided by the reduction in boll number per plant (Jost \& Cothren, 2000; Jost \& Cothren, 2001; Gwathmey \& Clement, 2010). In the castor bean crop, the number of racemes and the number of fruits/seeds per raceme (Soratto et al., 2011; Souza-Schlick et al., 2011) are also reduced.

After 1945, the plant density recommendation has gradually increased based on field observations and technical articles (Kittock \& Williams, 1970). Zimmerman (1958) suggested densities of about 30,000 ha-1 plants, while Brigham \& Spears (1961) suggested densities between 40,000 and 50,000 ha-1 plants for dwarf cultivars. Weiss (1983) reported irrigated crops in Russia and Romania with population densities of up to $60,000 \mathrm{ha}^{-1}$. In Brazil, the recommendations on plant density are still far below these values, mainly because of the predominance of larger-sized genotypes.

The response of castor bean to changes in plant population density is complex and involves ecophysiological aspects, since it causes many changes in growth and development (Beltrão et al., 2007). Changes in the phenotype as a function of changes in the environment are known as phenotypic plasticity (Bradshaw, 1965). Assessment of crop development and growth can provide information that helps guide recommendation on plant density.

The hypothesis that will be tested in this study is that high plant population densities limit the growth and development of new branches. Therefore, the objective of this study was to evaluate the effect of denser cultivation on the growth of dwarf castor bean genotypes.

\section{MATERIAL AND METHODS}

The experiment was conducted in the second crop season in 2011 and 2012, in an irrigated area at the Lageado Experimental Farm, belonging to the Faculdade de Ciências Agronômicas - UNESP, Botucatu-SP, 22'51'S, 48 26' W and, $740 \mathrm{~m}$ altitude. The soil of the experimental area is classified as a dystrophic Red Nitosol, with a clay texture (Embrapa, 2006).

The accumulated rainfall during the experimental period was $446 \mathrm{~mm}$ in 2011 and $865 \mathrm{~mm}$ in 2012. Precipitation data include records of the first four months of irrigation to allow adequate development. The amount water applied was $100 \mathrm{~mm}$ in 2011 and $40 \mathrm{~mm}$ in 2012.

The experiment was arranged in a split plot randomized block design, with four replications. The main plot consisted of the cutting times and the subplots consisted of a $3 \times 3$ factorial. The first factor was the 3 genotypes (two 
experimental hybrids of the UNESP-FCA Castor Bean Breeding Program and the commercial cultivar IAC 2028), and the second factor consisted of three plant densities (20, 40 and 80 thousand plants ha $\left.{ }^{-1}\right)$. Only three plant densities were evaluated due to the small production of experimental hybrid seeds.

In the year 2011, the hybrids used were designated Hybrid 1 (H1) and Hybrid 2 (H2). In 2011, the parental lines of Hybrid 1 and Hybrid 2 were removed from the UNESPFCA Castor Bean Breeding Program, hence, in 2012, other hybrids, which were designated as Hybrid 3 (H3) and Hybrid 4 (H4), were used in the experiment. The cultivar IAC 2028 was used in the two years of cultivation.

Each experimental unit consisted of four $0.45 \mathrm{~m}$ spaced rows, containing 16 plants per row. The soil chemical analysis was performed before the implementation of the experiment at the depth of 0 to $0.2 \mathrm{~m}$, with following results: $\mathrm{pH}$ in $\mathrm{CaCl}_{2}=4.8 ;$ O. M. $=20 \mathrm{~g} \mathrm{dm}^{-3} ; \mathrm{P}($ resin $)=25 \mathrm{mg} \mathrm{dm}^{-3}$;

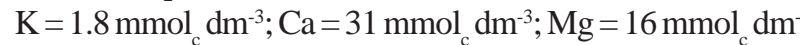
3; $\mathrm{H}+\mathrm{Al}=62 \mathrm{mmol}_{\mathrm{c}} \mathrm{dm}^{-3} ; \mathrm{SB}=49 \mathrm{mmol}_{\mathrm{c}} \mathrm{dm}^{-3} ; \mathrm{CTC}=110$ $\mathrm{mmol}_{\mathrm{c}} \mathrm{dm}^{-3}$ and $\mathrm{V} \%=44$ in 2011 and $\mathrm{pH}$ in $\mathrm{CaCl}_{2}=4.4$; O. $\mathrm{M} .=32 \mathrm{~g} \mathrm{dm}^{-3} ; \mathrm{P}($ resin $)=31 \mathrm{mg} \mathrm{dm}^{-3} ; \mathrm{K}=1.8 \mathrm{mmol}_{\mathrm{c}} \mathrm{dm}^{-3}$; $\mathrm{Ca}=23 \mathrm{mmol}_{\mathrm{c}} \mathrm{dm}^{-3} ; \mathrm{Mg}=8 \mathrm{mmol}_{\mathrm{c}} \mathrm{dm}^{-3} ; \mathrm{H}+\mathrm{Al}=81 \mathrm{mmol}_{\mathrm{c}}$ $\mathrm{dm}^{-3} ; \mathrm{SB}=33 \mathrm{mmol}_{\mathrm{c}} \mathrm{dm}^{-3} ; \mathrm{CTC}=113 \mathrm{mmol}_{\mathrm{c}} \mathrm{dm}^{-3}$ and $\mathrm{V} \%=$ 29 in 2012.

Fertilization at planting was carried out mechanically using $16 \mathrm{~kg} \mathrm{ha}^{-1} \mathrm{~N}, 56 \mathrm{~kg} \mathrm{ha}^{-1} \mathrm{P}_{2} \mathrm{O}_{5}$ and $32 \mathrm{~kg} \mathrm{ha}^{-1} \mathrm{~K}_{2} \mathrm{O}$. Topdress with $30 \mathrm{~kg} \mathrm{ha}^{-1} \mathrm{~K}_{2} \mathrm{O}$, in the form of potassium chloride, and $45 \mathrm{~kg} \mathrm{ha}^{-1} \mathrm{~N}$, in the form of urea, was carried out at $30 \mathrm{DAE}$. Sowing was carried out by hand on $03 / 03$ in 2011 and on 03/19 in 2012, using three seeds per hole. Seedling emergence occurred on March 24, 2011 and March 28,2012 . Thinning was performed at $12 \mathrm{DAE}$, leaving one plant per hole.

The variables analyzed were dry matter of leaves, stems, racemes and total dry matter, using destructive sampling. The petioles were included in the total dry matter. Sampling was performed at 30, 60, 90, 120 and 150 DAE, collecting two plants per experimental unit.

Data were examined for significant differences using analysis of variance followed by the F test $(\mathrm{p}<0.05)$. When a triple interaction was found, regression analysis ( $\mathrm{p}<$ 0.05 ) was performed for each factorial combination as a function of the samplings, using the statistical software Sisvar (Ferreira, 2011).

\section{RESULTS AND DISCUSSION}

There was triple interaction between the factors for all variables in the two years, except for the dry matter of racemes in 2011, where there was only interaction between samplings and plant densities and between samplings and genotypes.
Accumulation of total dry matter, in most treatments, stabilized at 150 DAE, in 2011 (Figure 1), except for the plant densities of 40 thousand and 80 thousand $\mathrm{ha}^{-1}$ of cultivar IAC 2028 (Figure $1 \mathrm{~h}$ and 1i). These last two treatments showed linear accumulation up to 150 DAE, which was a result of the longer cycle of the cultivar and a suppressive effect in the higher plant densities, delaying plant growth.

It is worth noting the large mass accumulation of $\mathrm{cv}$. IAC 2028, with the density of 20,000 plants ha ${ }^{-1}$ between 90 and 120 DAE, resulting in more than double the mass recorded for 40,000 plants ha ${ }^{-1}$ (Figures $1 \mathrm{~g}$ and $1 \mathrm{~h}$ ). This cultivar has a longer life cycle and larger size than the hybrids, which explains the greater accumulation of dry matter. Plants of all densities and of all genotypes formed primary and secondary organs. However, a vigorous growth of cv. IAC was recorded at the lowest density, at which plants had already formed tertiary organs. These organs function as a sink and reduce the production of the primary raceme, besides hampering the mechanized harvest due to uneven maturity and higher plant height. Fioreze et al. (2016) evaluated pruning and thinning of branches in cv. IAC 2028 and found lower yield of primary raceme in the control without pruning than the treatment which completely removed the secondary organs.

The current study found that, for all genotypes, the density of 20 thousand plants ha ${ }^{-1}$ produced higher dry matter than the density of 80 thousand plants $\mathrm{ha}^{-1}$. The dry matter of the two hybrids at the densities of 20,000 plants and 40,000 plants were similar, indicating that at the lower density the light resource was not fully exploited. Souza-Schlick et al. (2011) also observed a reduction in total dry matter with an increase in the population density from 25 thousand to 70 thousand ha ${ }^{-1}$ plants. Reduction in dry matter is desirable if there is reduction in number of branches and height, aiming at the mechanized harvest. Souza-Schlick (2013) reported a reduction in the dry matter of cv. IAC 2028 with application of the growth regulators mepiquat chloride, chlormequat chloride and trinexapacethyl, however, according to the author, the plant height remained high.

Increased plant density affects more strongly the accumulation of dry matter, but with less effect on the size. Usually, there is no effect of population density on plant height (Souza-Schlick et al., 2012; Soratto et al., 2011) and the opposite effect can take place, with a negative response to the increase in population density (Souza Schaeck et al., 2011), as it reduces the number of branches/racemes (Souza-Schlick et al., 2011; Kotz, 2012).

The total dry matter in 2012 showed a linear trend, increasing until the end of the period evaluated in all treatments (Figure 2). The steady growth was a response to the greatest rainfall in the year. This increase occurred 

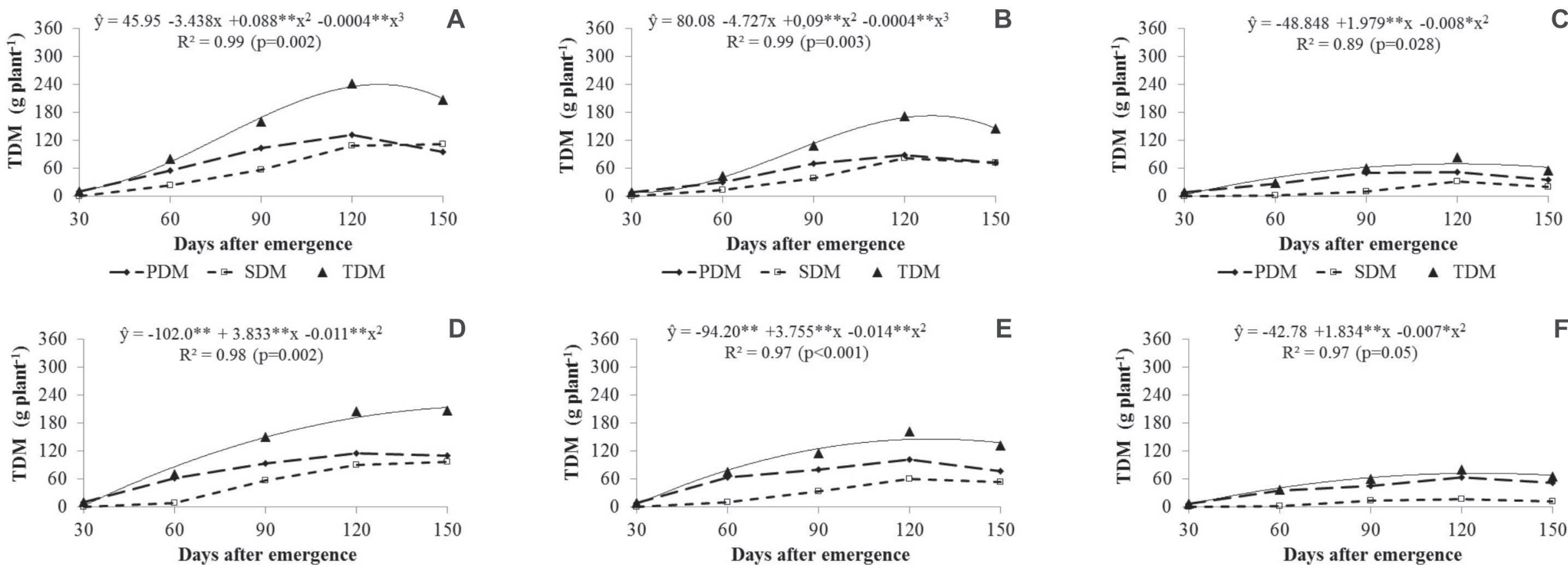

E $\rightarrow-\mathrm{PDM} \sim \mathrm{SDM} \triangle \mathrm{TDM}$

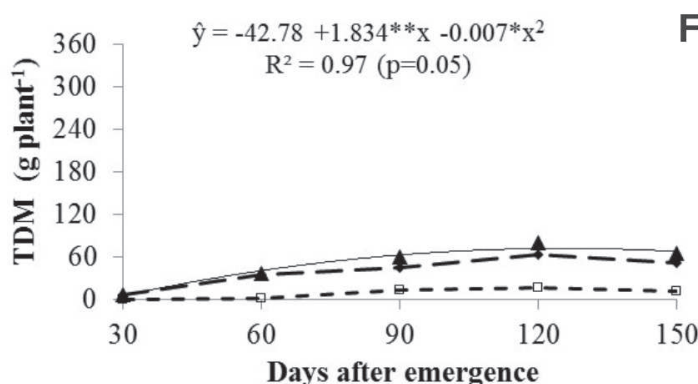

$\rightarrow-\mathrm{PDM} \rightarrow \mathrm{SDM} \wedge \mathrm{TDM}$

$\rightarrow-\mathrm{PDM}-\mathrm{SDM} \triangle \mathrm{TDM}$
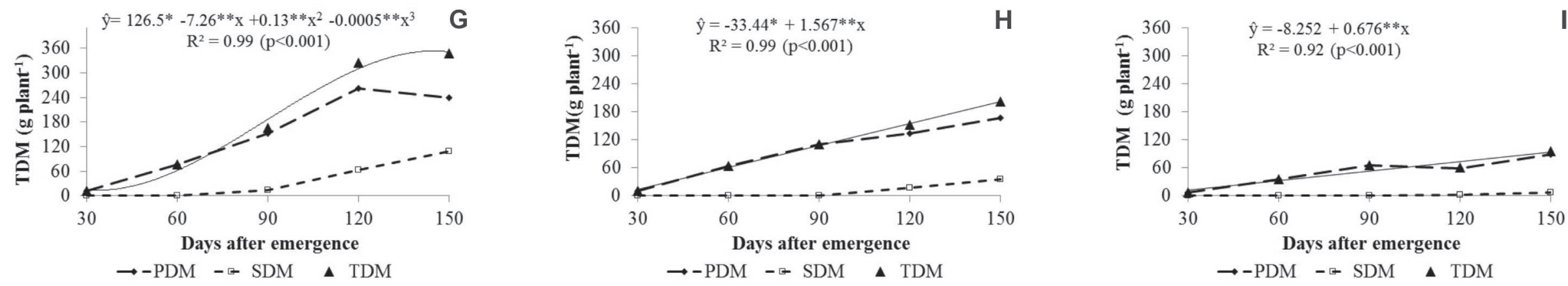

Figure 1: Total dry matter (TDM) as a function of genotypes and plant densities. (A) H1 20; (B) H1 40; (C) H1 80; (D) H2 20; (E) H2 40; (F) H2 80; (G) IAC 20; (H) IAC 40; (I) IAC 80. PDM - primary dry matter; SDM - secondary dry matter; TDM - total dry matter, in 2011. 


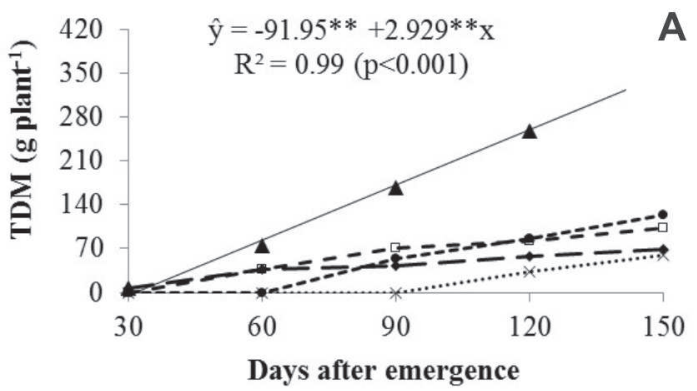

$\rightarrow-\mathrm{PDM} \rightarrow \mathrm{SDM} \rightarrow-\mathrm{TtDM} \cdot \cdots \cdot . . \mathrm{QDM} \quad$ ॥ TDM

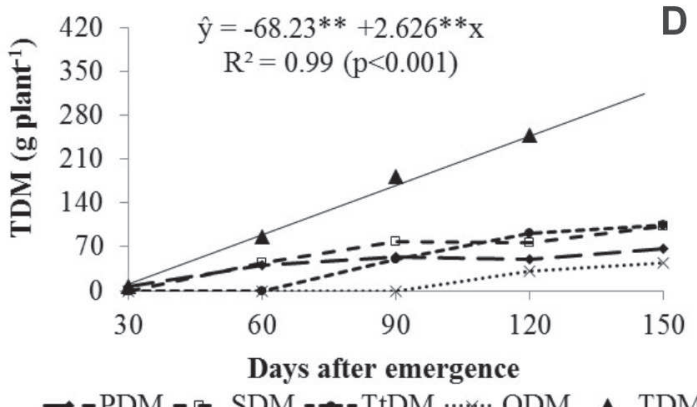

$\rightarrow-\mathrm{PDM}-\mathrm{SDM} \rightarrow-\mathrm{TtDM} \cdots, . . \mathrm{QDM}$ ॥ TDM

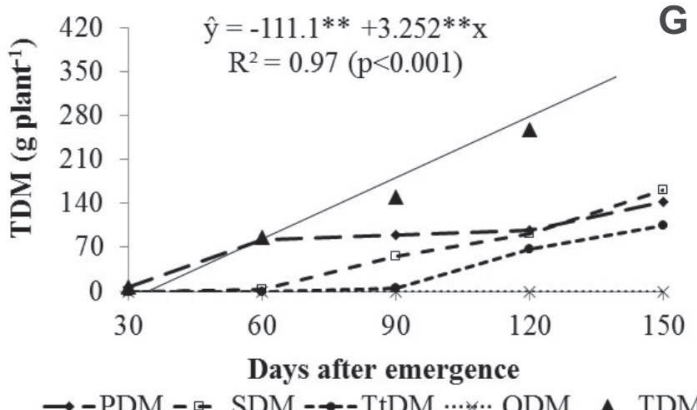

G

$\rightarrow-P D M-a$ SDM $\rightarrow-T$ tDM $\cdots$... QDM \& TDM

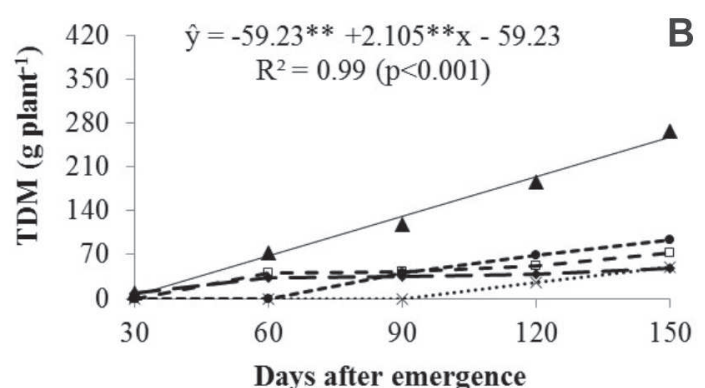

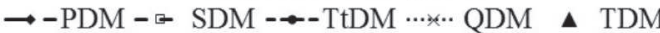

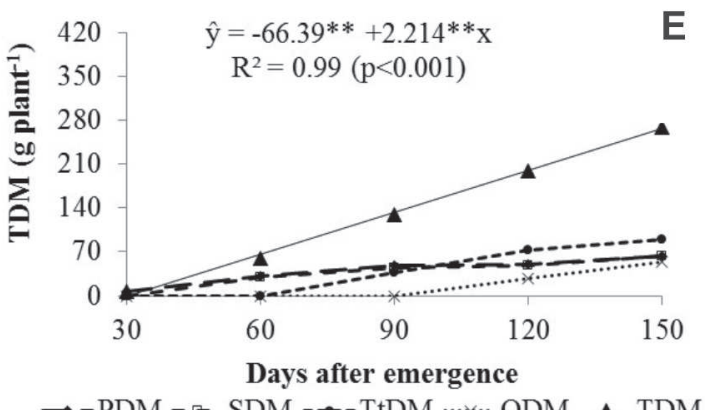

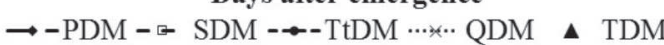

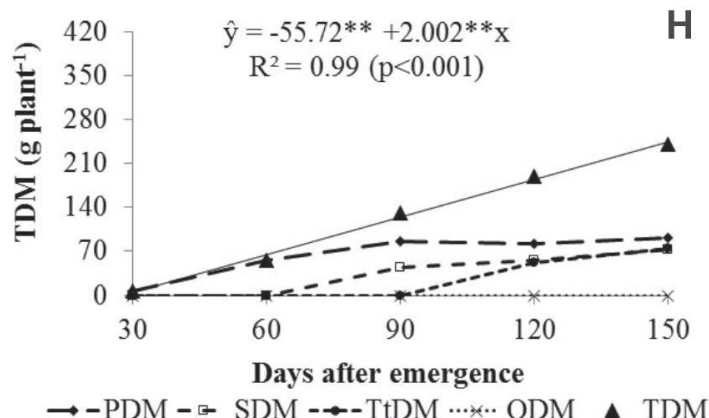

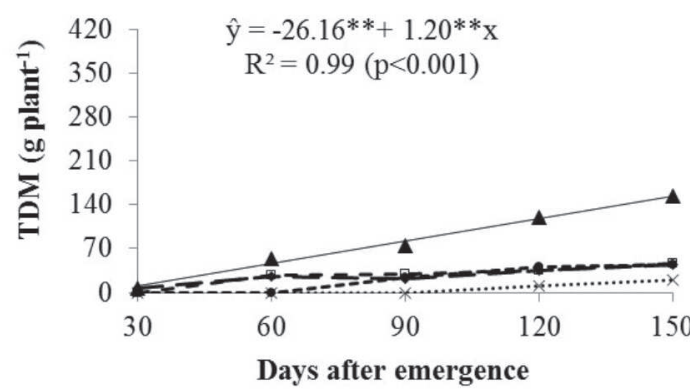

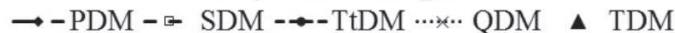

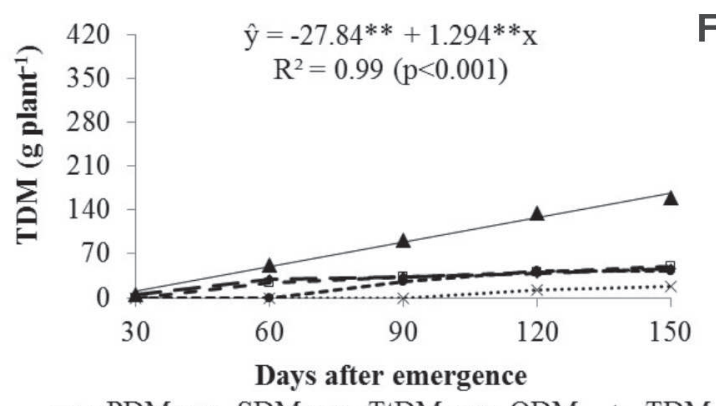

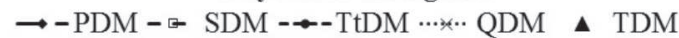

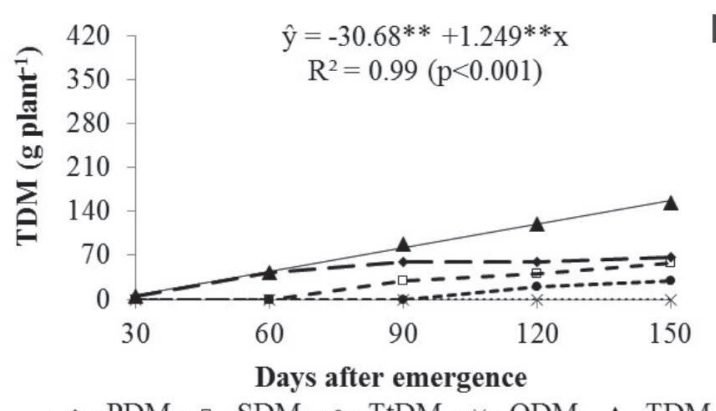

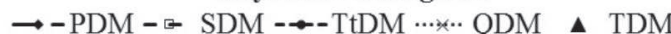

Figure 2: Total dry matter (TDM) as a function of plant genotypes and population densities. (A) H3 20; (B) H3 40; (C) H3 80; (D) H4 20; (E) H4 40; (F) H4 80; (G) IAC 20; (H) IAC 40; (I)

IAC 80. PDM - primary dry matter; SDM - secondary dry matter; TtDM - tertiary dry matter; QDM - quaternary dry matter; TDM - total dry matter, in 2012. 
even in the treatments with plant density of 80 thousand plants ha-1 ${ }^{-1}$ but it was less intense than at the density of 20 thousand plants ha-1 which is shown by the difference in the final growth, between 120 and 150 DAE. All hybrids, even at the highest density, formed quaternary organs, while cv. IAC 2028 formed tertiary organs. This response, despite providing higher yield due to the higher number of racemes, is not desirable because it increases plant size and uneven maturity among the racemes, resulting in losses in the mechanized harvest.

Overall, the main difference among the genotypes occurred in the treatment with 20 thousand plants ha ${ }^{-1}$. At this plant density, cv. IAC 2028 showed higher growth than the hybrids at the end of the period evaluated (Figures $2 \mathrm{a}, 2 \mathrm{~d}$ and $2 \mathrm{~g}$ ). These results partly differ from Alves $e t$ al.'s (2015) report on the growth of cv. BRS Energia, which showed that plant height stabilized from 45 DAE onwards, even in irrigated area.

The stem dry matter response of the genotypes was considerably different between hybrids and cultivar IAC 2028 in 2011 (Figure 3). While there was a reduction in stem dry matter of hybrids at 150 DAE in all densities (Figures 3a, 3b, 3c, 3d, 3e and 3f), cv. IAC 2028 showed no reduction at densities of 40 thousand plants ha ${ }^{-1}$ and 80 thousand plants ha ${ }^{-1}$ (Figure $3 \mathrm{~h}$ and $3 \mathrm{i}$ ). The decrease in dry matter at the end of development may have been caused by the remobilization of photoassimilates. The carbon fixed in a source cell can be used for transport, metabolism, or storage, and starch is the main form of reserve stored in chloroplasts (Taiz \& Zaiger, 2004). Photoassimilates stored in the stem can be allocated to other parts of the plant. At this moment, the stem becomes a source organ, remobilizing assimilates to sinks such as seeds (Magalhães \& Jones, 1990).

In this study, the stem dry matter was lower at higher population densities for all genotypes (Figure 3). However, the reduction was more intense in cv. IAC 2028, as revealed by the great difference among the plant densities (Figure $3 c)$. In the hybrids, the difference among densities was much lower, and stem dry matter at 40,000 plants ha ${ }^{-1}$ was the same as that at the lowest density. This shows the greater tolerance of hybrids to increased plant density.

Stem dry matter accumulation was higher in 2012 than in 2011 because of the higher rainfall (Figures 3 and 4). Hybrids even developed quaternary stems. One of the hypotheses at the conception of the project was that under high population densities the plant would develop similarly to an annual crop, by completing the cycle and facilitating mechanization of harvest. This supposition was confirmed in 2011, notably at higher densities, however, it was due to the lower availability of water.

Besides accumulating greater stem dry matter in 2012, this increase was continued until 150 DAE. This behavior also occurred for all stem orders. In 2011, the reduction in total dry matter at the end of the period evaluated reflected the reduction in dry matter of primary stems. Considering that there was less available water in 2011 and the cycle was reduced in approximately 30 days, it is suggested that the plant had allocated the reserves to the seeds, firstly from the primary stems. Machado et al. (1992) evaluated the remobilization of reserves in two hybrids of maize under water deficiency after flowering and found a reduction in stem dry matter only in the treatments with water deficiency.

The leaf dry matter response in 2011 was the same for all genotypes and plant densities. There was an increase in mass because of the production of new leaves and the increase in leaf area, and afterwards a reduction in mass as a function of leaf senescence and fall (Figure 5). One difference to be highlighted is that at the lowest density, cv. IAC 2028 showed continued growth up to 120 DAE. Another interesting response is that hybrids 1 and 2, at the three plant densities, had lost nearly all leaves at the end of the period evaluated. Because of the lower water availability, the hybrids behaved as an annual crop, losing all the leaves and completing the cycle. This is the ideal scenario to enable mechanization of the crop and expansion to large cultivation areas of the Cerrado. It is also interesting to note that leaf fall in all genotypes was more intense at the density of 80,000 plants $\mathrm{ha}^{-1}$.

The results of leaf dry matter in 2012 show that, in general, mass stabilized at 150 DAE (Figure 6), except for the treatments Hybrid 4 at the density of 40,000 plants ha${ }^{1}$ (Figure 6e) and cv. IAC 2028 at 20,000 plants ha ${ }^{-1}$ (Figure $6 \mathrm{~g}$ ), which had continued mass accumulation. In both years, the smallest populations had the highest dry matter. Kotz (2012) observed a higher number of leaves in the treatment with the lowest plant density in the two years of cultivation. The largest number of leaves produced resulted in larger leaf area and higher dry matter of leaves per plant.

The accumulation of leaf dry matter in a plant aims to maintain the photosynthetic activity, thus, the castor bean plant needs to produce lateral branches to increase its leaf area. In the current study, the primary leaves of experiment in 2012 had a shorter life span than in 2011, even with higher water availability.

In adequate environmental conditions, the plant produces new branches, which are vegetative sinks, and they shade the primary leaves. This shading may impair the production of the primary racemes. The opposite effect has already been observed by Fioreze et al. (2016), who investigated the effect of thinning secondary structures on castor bean and observed an increase in the length of the primary raceme, demonstrating the sink effect caused by higher order plant organs. However, it is uncertain to say, between the shading and the strength of secondary 


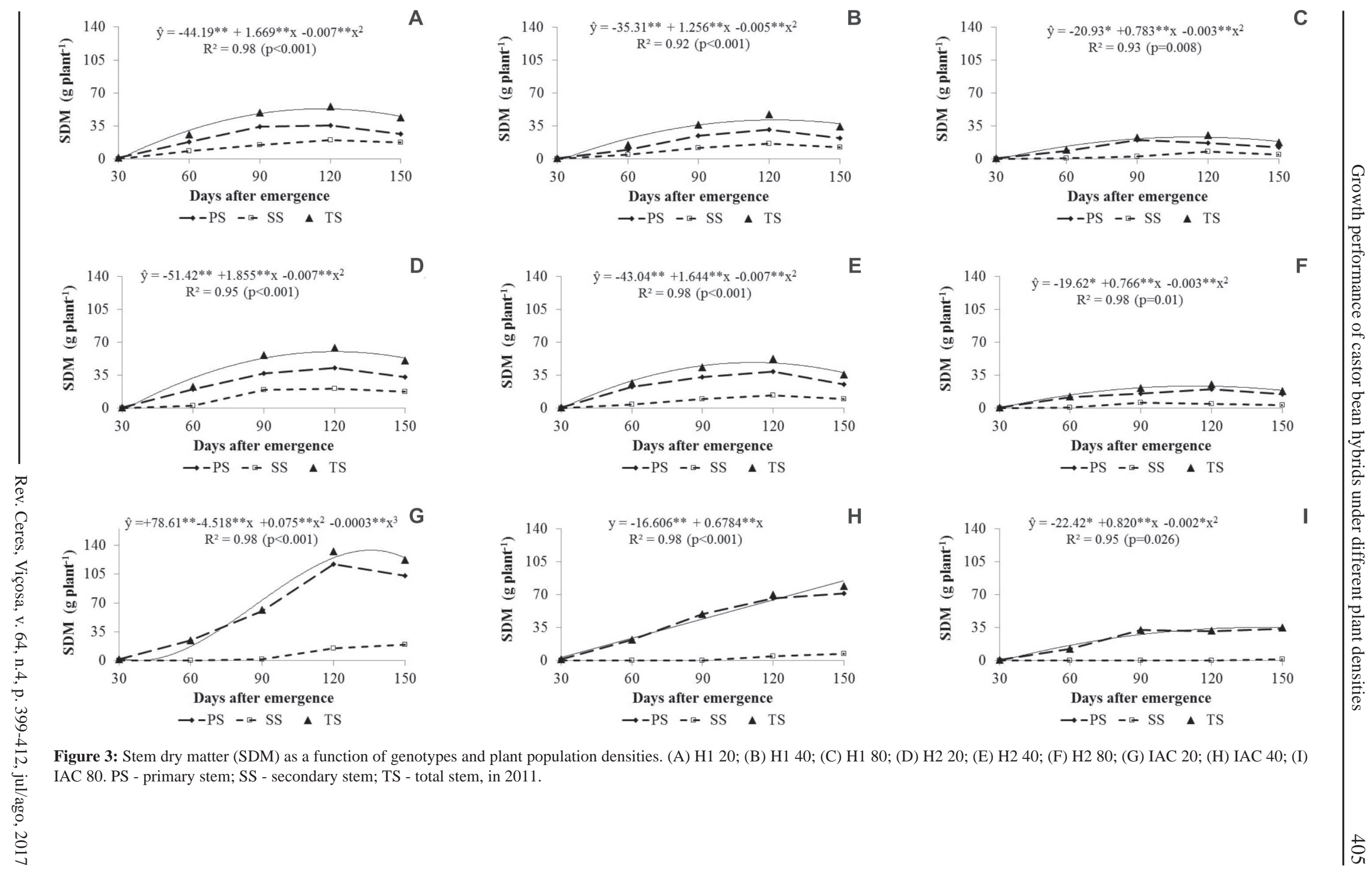



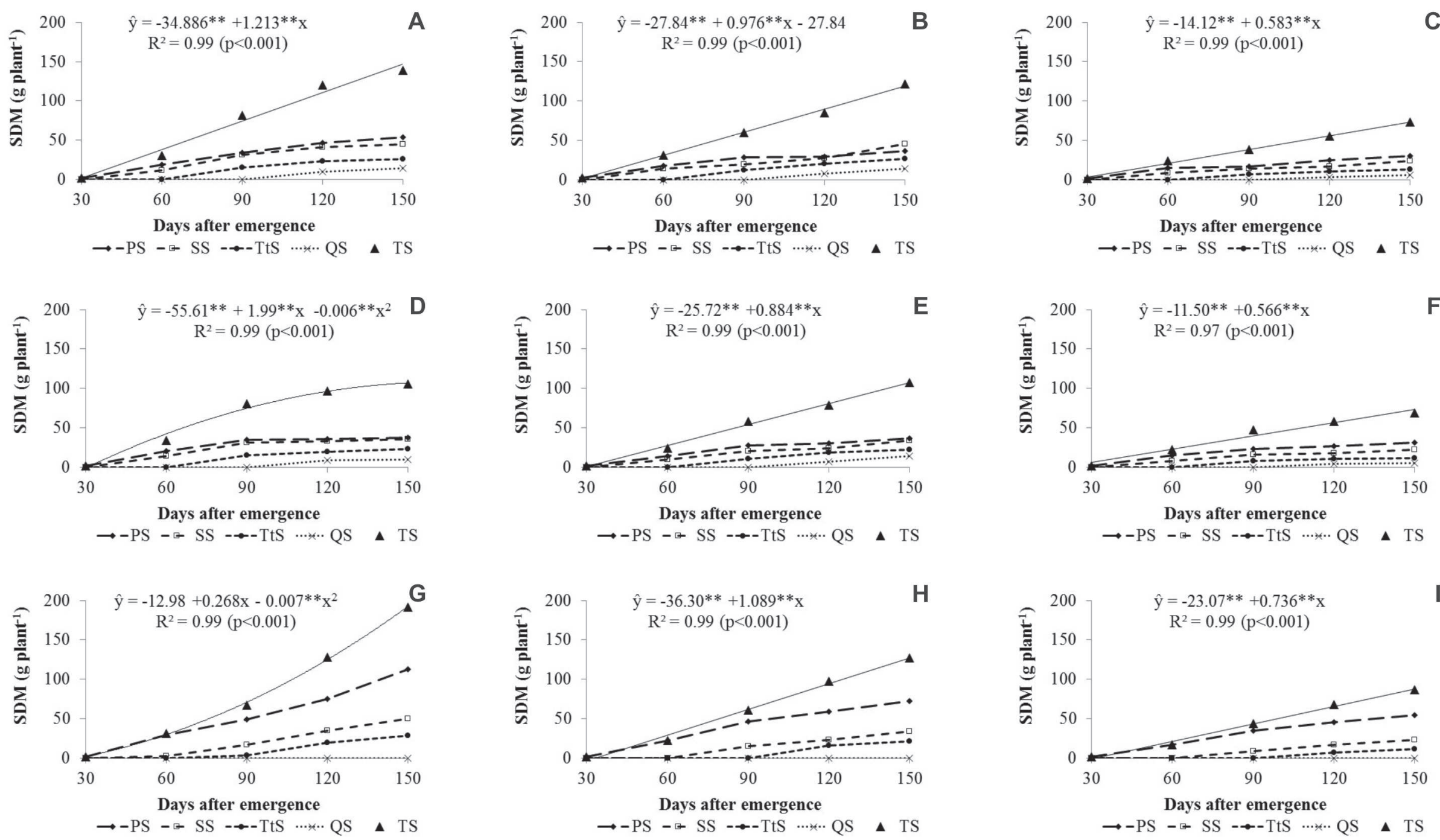

Figure 4: Stem dry matter mass (SDM) as a function of genotypes and plant population densities. (A) H3 20; (B) H3 40; (C) H3 80; (D) H4 20; (E) H4 40; (F) H4 80; (G) IAC 20; (H) IAC 40; (I) IAC 80. PS - primary stem; SS - secondary stem; TtS - tertiary stem; QS - quaternary stem; TS - total stem, in 2012. 


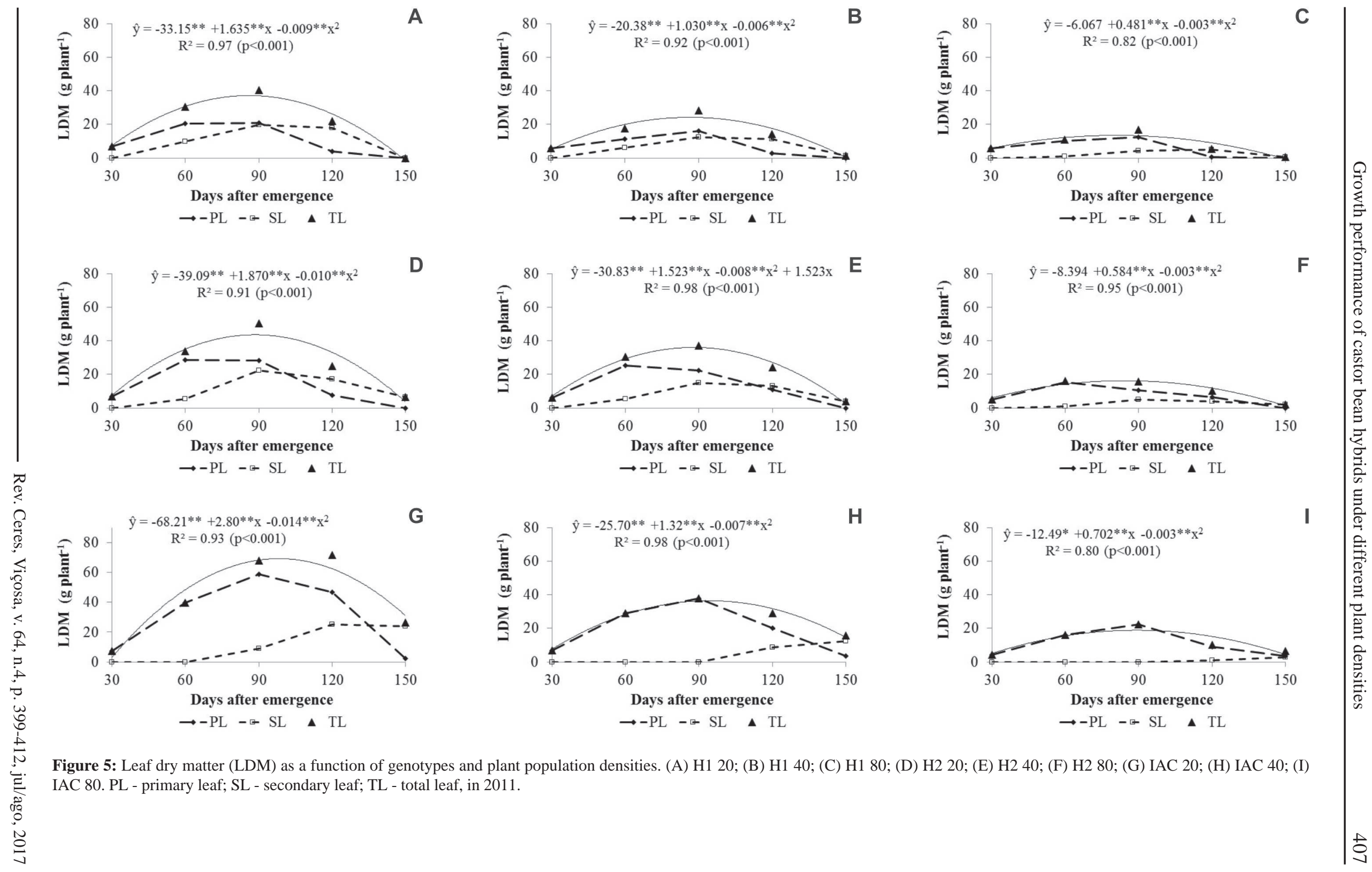



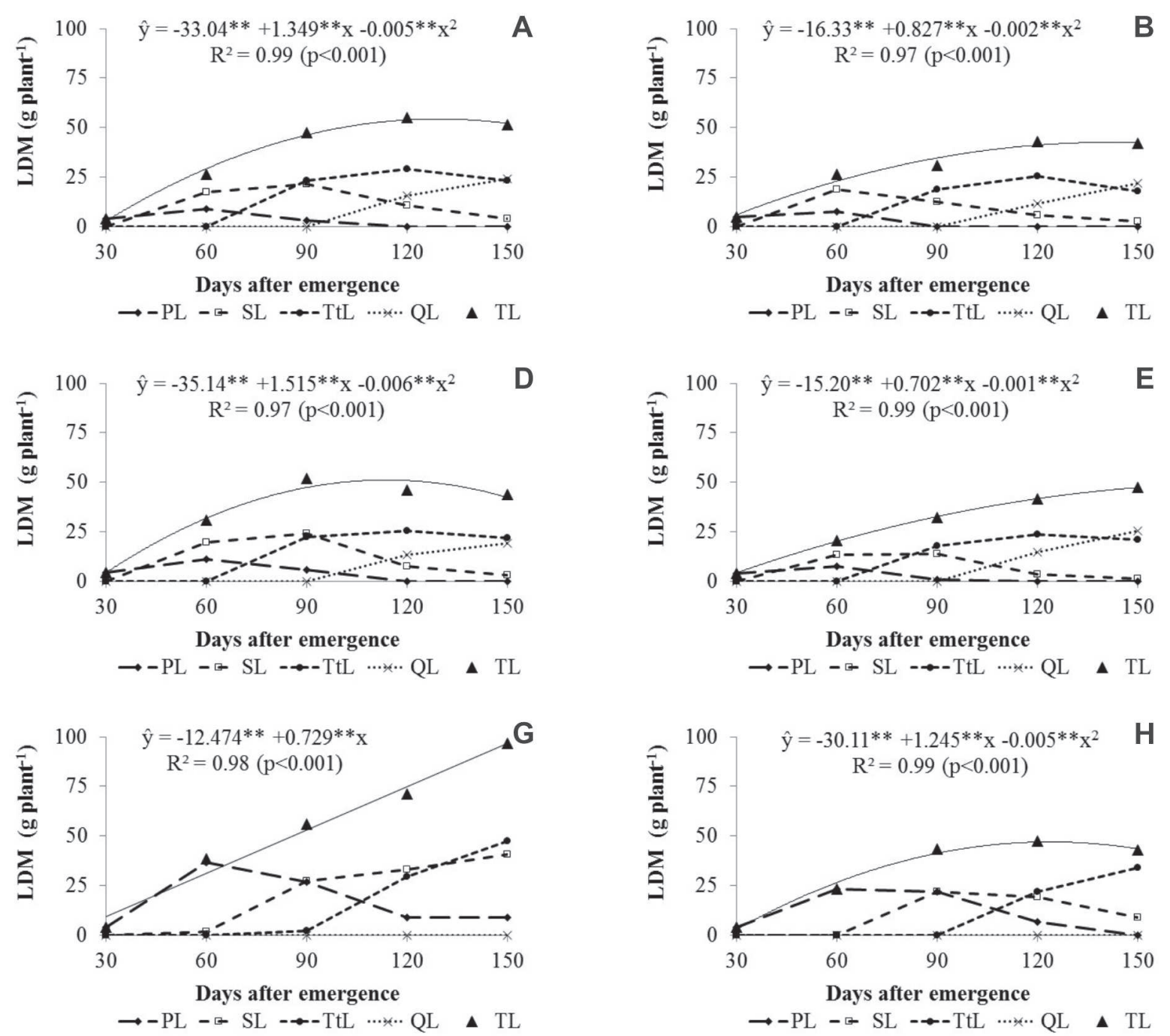
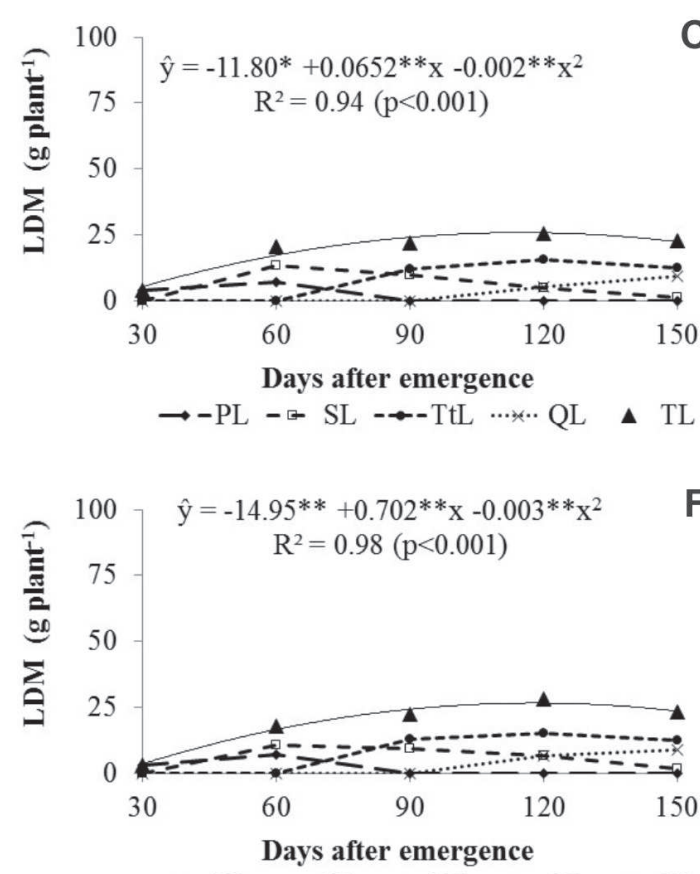

$\rightarrow-\mathrm{PL} \rightarrow \mathrm{SL} \rightarrow \mathrm{TtL} \cdots \cdot . \cdot \mathrm{QL} \quad \boldsymbol{\Delta} \mathrm{TL}$

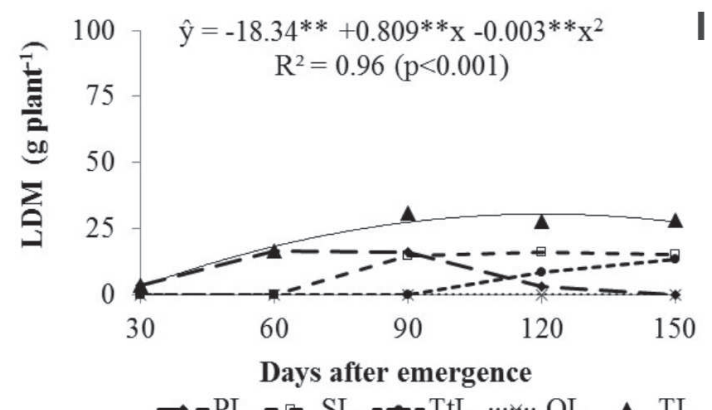

Figure 6: Leaf dry matter (LDM) as a function of genotypes and plant population densities(A) H3 20; (B) H3 40; (C) H3 80; (D) H4 20; (E) H4 40; (F) H4 80; (G) IAC 20; (H) IAC 40; (I) IAC 80. PL - primary leaf; SL - secondary leaf; TtL - tertiary leaf; QL - quaternary sheet; TL - total leaf, in 2012. 

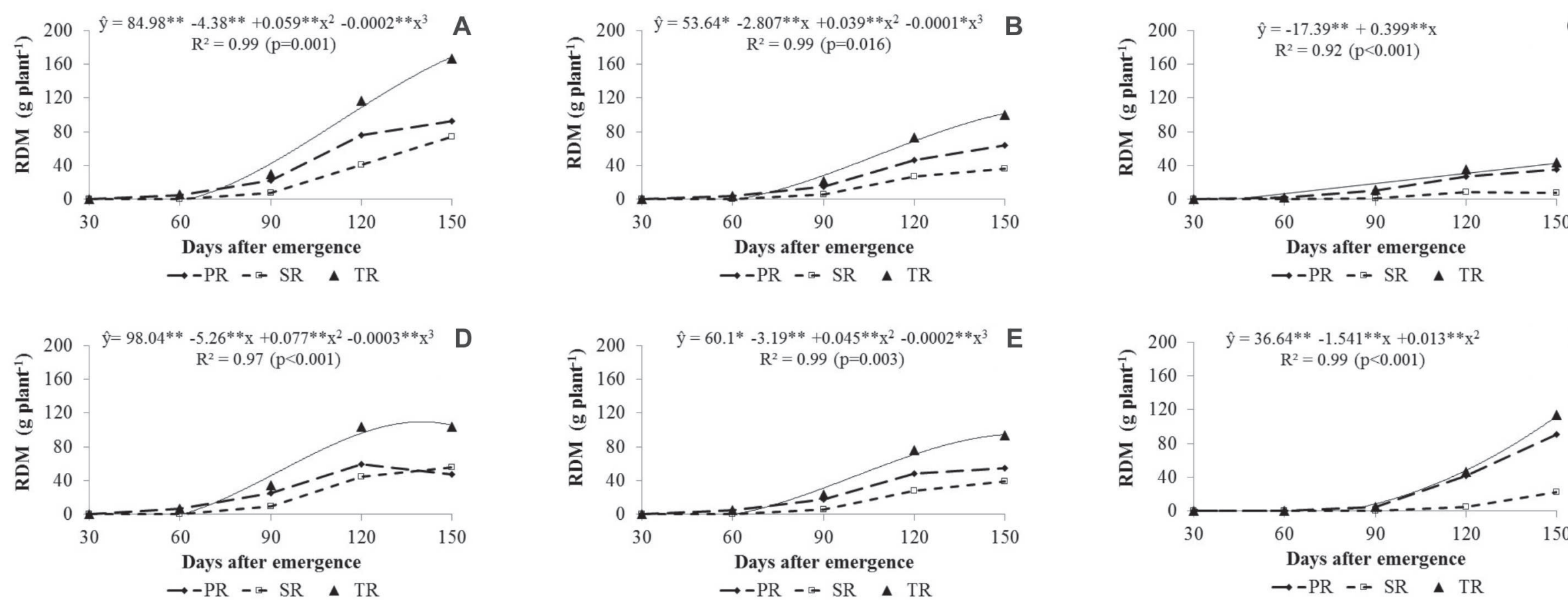

Figure 7: Raceme dry matter (RDM) as a function of genotypes and plant population densities. (A) 20,000 plants ha ${ }^{-1}$; (B) 40,000 plants ha ${ }^{-1}$; (C) 80,000 ha-1 plants; (D) Hybrid 1; (E) Hybrid 2; (F) IAC 2028. PR - primary raceme; SR - secondary raceme; TR - total raceme, in 2011. 

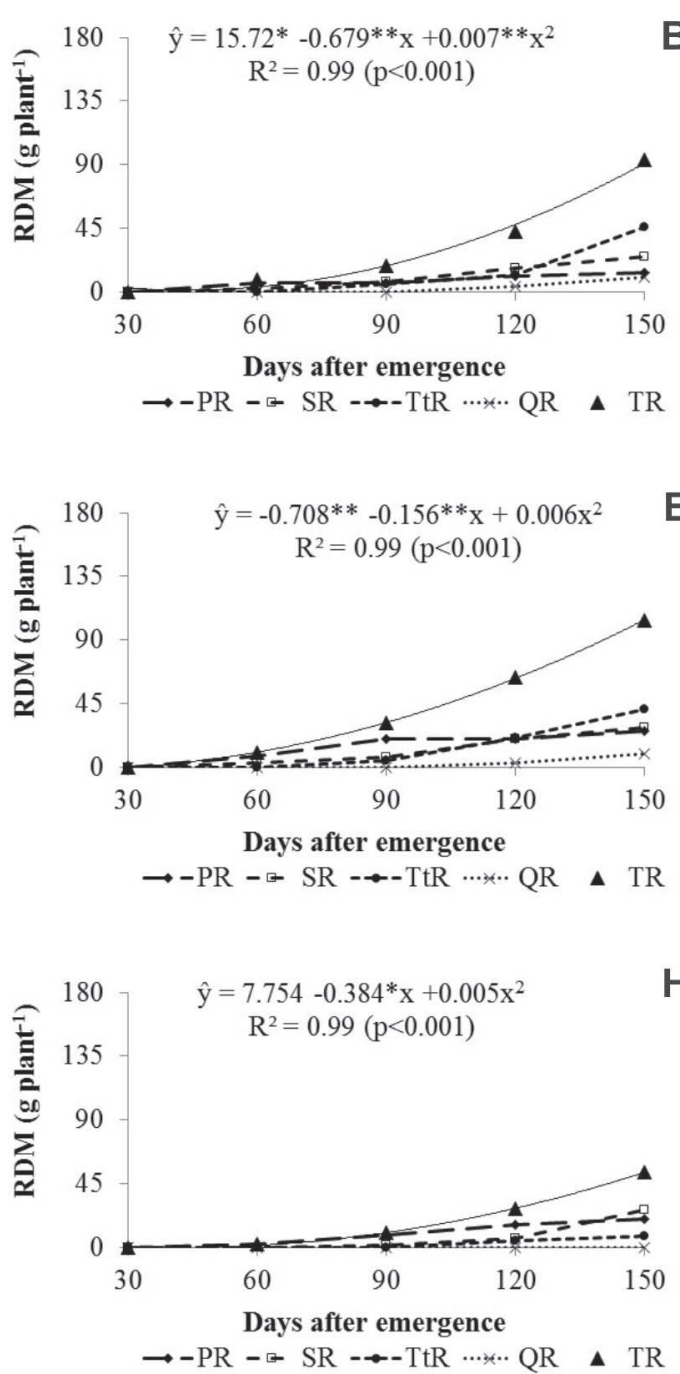
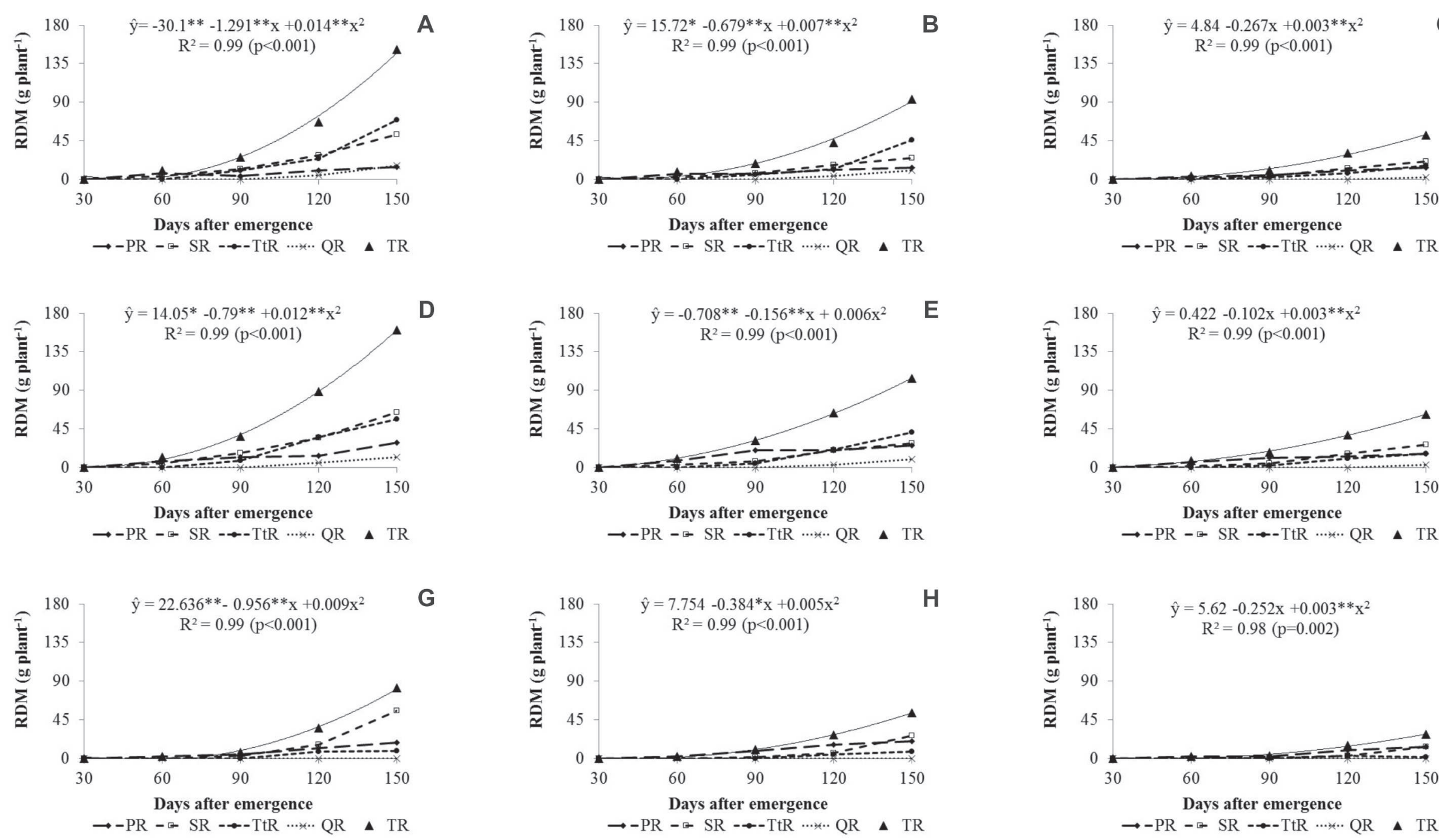

\section{G}
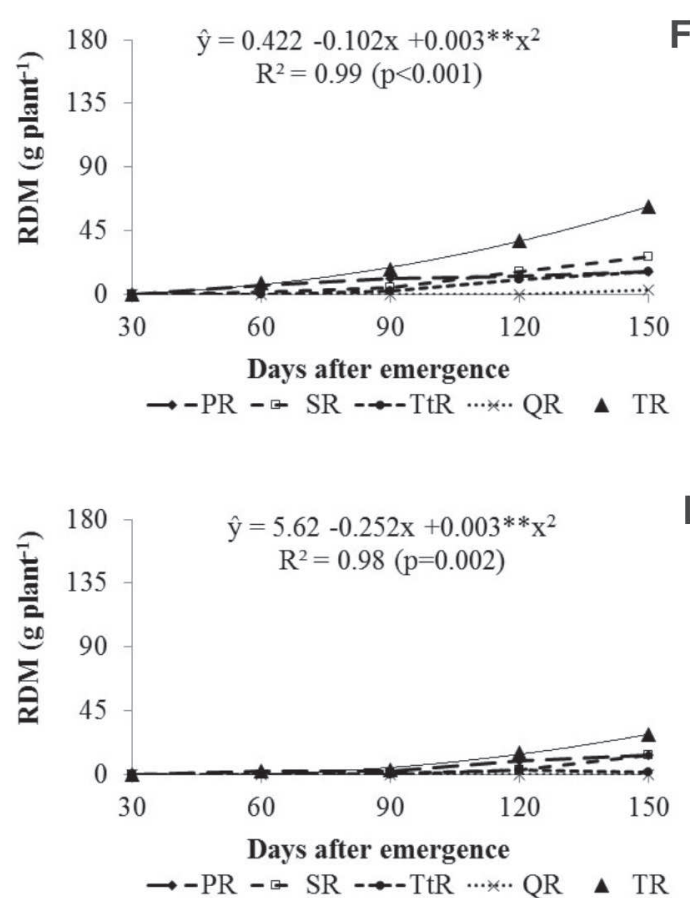

Figure 8: Raceme dry matter (RDM) as a function of genotypes and plant population densities. (A) H3 20; (B) H3 40; (C) H3 80; (D) H4 20; (E) H4 40; (F) H4 80; (G) IAC 20; (H) IAC 40; (I) IAC 80. PR - primary raceme; SR - secondary raceme; TtR - tertiary raceme; QR - quaternary raceme; TR - total raceme, in 2012. 
organ sink, which is the main factor in the senescence of the primary leaves, since both occur simultaneously. According to Severino \& Auld (2013), the plant regulates the leaf longevity based on evolutionary responses and a long leaf life span would only be advantageous if it could maintain high photosynthetic capacity. Limiting light is one of the factors that influence senescence (Lim et al., 2007). Then, under shading and low photosynthetic activity, the plant uses the strategy called programmed cell death (PCD), and senescent leaf has a specific type of PCD. One of the biological functions of programmed cell death is to promote the remobilization of nutrients and reserves from the leaves to other sink organs (Lim et al., 2007).

Raceme dry matter of per plant in 2011 showed considerable differences among the plant densities (Figure 7), and the plants at the lowest plant density had the largest accumulation. The genotypes had similar total accumulation, but raceme dry matter of Hybrids 1 and 2 (Figure $7 \mathrm{~d}$ and $7 \mathrm{e}$ ) stabilized at $150 \mathrm{DAE}$, while cv. IAC 2028 (Figure 7f) showed continued increase until the end of the period evaluated. This response was due to the longer cycle compared with the hybrids. Figure $7 \mathrm{f}$ shows that cv. IAC 2028 had very low raceme dry matter at 90 DAE.

In 2012, raceme dry matter per plant increasingly accumulated up to 150 DAE in all treatments (Figure 8), especially at lowest plant densities, which showed the highest accumulations. This finding agrees with Kotz (2012), who compared the raceme dry matter of cv. IAC 2028 at different plant densities (50 thousand to 95 thousand plants $\mathrm{ha}^{-1}$ ) in second crop using a denser spacing ( $0.45 \mathrm{~m}$ between rows) with the control treatment ( 25 thousand plants ha ${ }^{-1} \times 0,90 \mathrm{~m}$ between rows) and found that the lowest plant densities produced the highest raceme dry matter.

Differently from that observed for the other variables, in 2012, even with greater water availability, there was lower accumulation of raceme dry matter compared with 2011 (Figures 7 and 8). This is probably an evolutionary response in which the plant takes advantage of the available resources, produces a greater photosynthetic area and accumulates photoassimilates in the stems. In the future, this investment in vegetative organs will result in translocation of reserves and accumulation of seed dry matter.

This study has shown that that castor bean has a high phenotypic plasticity, and this characteristic can be used in the development of a plant ideotype with a focus on mechanized harvesting. The reduction in rains during the second crop in the Cerrado should be used, in combination with denser spacing, to stop the vegetative growth and end the cycle of the crop, aiming to reduce the number of branches. Despite the delay in growth, it is known that the crop tolerates high densities without affecting yield, as noted by Fioreze et al. (2016), who found no difference in the yield between the densities of 26,666 and 111,111 plants $\mathrm{ha}^{-1}$. Considering that in a mechanized harvest, a large number of racemes per plant will cause losses in the platform, high plant densities may produce higher yields than low densities, however, the increase in seed cost must be taken into account.

\section{CONCLUSIONS}

The hybrids showed better performance due to less growth at the end of the cycle, the characteristic of the early fall of all leaves in 2011, and the early accumulation of dry matter by racemes.

The best performance of castor bean at high plant densities is due to the shorter height and more intense leaf fall.

\section{REFERENCES}

Alves GS, Tartaglia FL, Ferreira MM, Beutler NA \& Santos EC (2015) Análise de crescimento da mamoneira BRS Energia em função da densidade populacional. Revista Caatinga, 28:167175

Beltrão NEM, Azevedo DMP, Lima RLS, Queiroz WN \& Queiroz WC (2007) Ecofisiologia. In: Azevedo DMP \& Beltrão NEM (Eds.) O agronegócio da mamona no Brasil. 2 ${ }^{\mathrm{a}}$ ed. Campina Grande, Embrapa Algodão - Brasília, Embrapa Informação Tecnológica. p.45-72.

Bradshaw AD (1965) Evolutionary significance of phenotypic plasticity in plants. Advances in Genetics, 13:115-155.

Brigham RD \& Spears BR (1961) Castorbeans in Texas. Weslaco, Texas Agricultural Experiment Station. 11p. (Bulletin, 954).

Chierice GO \& Claro Neto S (2007) Aplicação Industrial do Óleo. In: Azevedo DMP \& Beltrão NEM (Eds.) O agronegócio da mamona no Brasil. $2^{a}$ ed. Campina Grande, Embrapa Algodão Brasília, Embrapa Informação Tecnológica. p.417-448.

Dallacort R, Martins JA, Inoue MH, Freitas PRL \& Colleti AJ (2011) Distribuição das chuvas no município de Tangará da Serra, médio norte do Estado de Mato Grosso, Brasil. Acta Scientiarum Agronomy, 33:193-200.

Embrapa - Empresa Brasileira de Pesquisa Agropecuária (2006) Sistema brasileiro de classificação de solos. Brasília, EmbrapaCNPS. 306p.

Ferreira DF (2011) Sisvar: a computer statistical analysis system. Ciência e Agrotecnologia, 35:1039-1042.

Fioreze SL, Lara-Fioreze ACC, Pivetta LG, Rodrigues JD \& Zanotto MD (2016) Características agronômicas da mamoneira afetadas pelo método de condução de plantas e densidade de semeadura. Ciência Agronômica, 47:86-92.

FAO - Food and Agriculture Organization of the United Nations (2014) Crops - Castor oil seed. Disponível em: <http:// www.fao.org/faostat/en/\#data/QC>. Acessado em: 13 de janeiro de 2017.

Gwathmey CO \& Clement JD (2010) Alteration of cotton sourcesink relations with plant population density and mepiquat chloride. Field Crops Research, 116:101-107. 
Jost PH \& Cothren JT (2000) Growth and yield comparisons of cotton planted in conventional and ultra-narrow row spacings Crop Science, 40:430-435.

Jost PH \& Cothren JT (2001) Phenotypic alterations and crop maturity differences in ultra-narrow row and conventionally spaced cotton. Crop Science, 41:1150-1159.

Kittock DL \& Williams JH (1970) Effects of plant population on castor bean yield. Agronomy Journal, 62:527-529.

Kotz TE (2012) Crescimento e produtividade da mamoneira IAC 2028 na safrinha em função da densidade populacional de plantas em espaçamento reduzido. Dissertação de Mestrado. Universidade Estadual Paulista "Júlio De Mesquita Filho", Botucatu. $71 \mathrm{p}$.

Lim PO, Kim HJ \& Nan HG (2007) Leaf senescence. Annual Review of Plant Biology, 58:115-136.

Machado EC, Silveira JAG, Vitorello VA \& Rodrigues JLA (1992) Fotossíntese, remobilização de reservas e crescimento de grãos de dois híbridos de milho sob deficiência hídrica na fase de enchimento dos grãos. Bragantia, 51:151-159.

Magalhães PC \& Jones R (1990) Aumento de fotoassimilados na taxa de crescimento e peso final dos grãos de milho. Pesquisa Agropecuária Brasileira, 25:1747-1754.

Moshkin VA (1986) Castor. Rotterdam, Balkenma. 315p.

Rangel LEP, Ferreira LG, Almeida VM \& Menezes VL (2003) Mamona: Situação Atual e Perspectivas no Mato Grosso. Campina Grande, Embrapa Algodão. 20p. (Documentos, 106).

Santos RF, Kouri J, Barros MAL, Marques FM, Firmino PT \& Requião LEG (2007) Aspectos econômicos do agronegócio da mamona. In: Azevedo DMP \& Beltrão NEM (Eds.) O agronegócio da mamona no Brasil. 2a ed. Campina Grande, Embrapa Algodão - Brasília, Embrapa Informação Tecnológica. p.21-42.
Savy Filho A (1999) Hibridação em mamoma. In: Borém A (Ed.) Hibridação Artificial de Plantas. Viçosa, UFV. p.331-342.

Severino LS \& Auld DL (2013) A framework for the study of the growth and development of castor plant. Industrial Crops and Products, 46:25-38.

Soratto RP, Souza-Schlick GD, Giacomo BMS, Zanotto MD \& Fernandes AM (2011) Espaçamento e densidade populacional de plantas de mamoneira de porte baixo para colheita mecanizada. Pesquisa Agropecuária Brasileira, 46:245-253.

Souza-Schlick GD, Soratto RP, Pasquali CB \& Fernandes AM (2011) Desempenho da mamoneira IAC 2028 em função do espaçamento entre fileiras e densidade populacional de plantas na safrinha. Bragantia, 70:519-528.

Souza-Schlick GD, Soratto RP, Bottino D \& Fernandes AM (2012) Crescimento e produtividade da mamona de porte baixo em diferentes espaçamentos e densidades populacionais de plantas. Interciencia, 37:49-54.

Souza-Schlick GD (2013) Reguladores vegetais para o manejo do porte da mamoneira IAC 2028. Tese de Doutorado. Universidade Estadual Paulista "Júlio De Mesquita Filho", Botucatu. 128p.

Taiz L \& Zieger E (2004) Fisiologia Vegetal. Porto Alegre, Artmed. $719 \mathrm{p}$.

Weiss EA (1983) Oilseed crops. London, Longman. 659p.

Zimmerman LH (1958) Castorbeans: a new oil crop for mechanized production. Advances in Agronomy, 10:257-288. 